\title{
OPIS ŽENSKE LJEPOTE U PJESNIČKOJ TRADICIJI EUROPSKIH BALADA I U PETRARKISTIČKIM PJESMAMA
}

Prethodno priopćenje

Primljeno: 5. 6. 2017.

Prihvaćeno: 24. 10. 2017.

DOI: $10.15176 /$ vol54no203

UDK 82.091

821.134.2.09-1:39

821.163.42.09-1:39

\section{SIMONA DELIĆ}

Institut za etnologiju i folkloristiku, Zagreb

\begin{abstract}
U ovome članku pokušali smo ukratko predstaviti lirske opise motiva ženske ljepote U tradicijskom španjolskom i u hrvatskom usmenom pjesništvu zaustavivši se posebno na petrarkističkim pjesmama (talijanskim, španjolskim) s motivom carpe diem. lako usamljen $u$ kontekstu hrvatskog tradicijskog pjesništva, fragment s motivom opisa ženske ljepote iz epske pjesme pjevačice Kate Murat iz Šipanske Luke na dubrovačkom Elafitskom otoku Šipanu zaslužuje posebnu pozornost jer motivom "našminkane" ljepote omogućuje komparatističko prepoznavanje formulaičnog opisa ženske ljepote u usmenome i pisanome pjesništvu u komparatističkome kontekstu (na tragu francuskog znanstvenika Paula Zumthora). Taj formulaični opis u širem književnom kontekstu omogućio nam je i prepoznavanje zajedničke antropološke niše iz koje je motiv carpe diem potekao.
\end{abstract}

Ključne riječi: petrarkističke pjesme, baladno pjesništvo, formulaični opis ženske ljepote, Paul Zumthor, Kate Murat, kazivačica priča

\section{UVODNE NAPOMENE}

Renesansni koncept ljepote koji prožima petrarkističke pjesme, kako se može prepoznati u svjetlu optimizma geografskih otkrića, revolucionarnih znanstvenih spoznaja i renesansnih slikarskih ikonografskih prikaza (Mantegna, Rafael), prisutan je i u pjesničkom diskursu moderne tradicije europskih balada. Elitna i pučka kultura, barem kad je riječ o descriptio mulieris, ne razlikuju se previše; štoviše, međusobno se prožimaju. Željeli bismo u ovom članku pokazati povezanost onodobnih traktata o ljepoti i knjiga recepata o kozmetici, zdravlju i higijeni, nastalih vjerojatno na temelju starih zapisa i priručnika (usp. Martínez Crespo 1995), ali i orijentalnih filozofskih traktata o higijeni (Avicenna), pa i pučkih savjet- 
nika, koji su svoj odraz našli u mediteranskom arealu petrarkističkih pjesama. Naime, ovaj rad polazi od mišljenja kako su talijanske balade nastale na podlozi ili u bliskom doticaju s petrarkističkim pjesmama. Hrvatska usmena tradicija je, slijedom tog fenomena, svoj usmenoknjiževni diskurs pokušala uskladiti s pjesničkim diskursom domaćih petrarkista. Štoviše, opozicija seosko-urbano i seosko-građansko pokušava se zagladiti u istovrsnim formulama ženske ljepote.

No, suvremeno historiografsko očište problematizira monolitnost i jednoobraznost renesanse kako u odnosu na antiku i srednjovjekovlje tako i u odnosu na moderno doba huizingovskog profila:

"Problem renesanse" pod terminom renesanse podrazumijeva purpur i zlato, svijet svečanosti koji se kupa u blagoj svjetlosti i čistoći, u svemu nešto pozitivno; to je sanjar burckhardtovskog tipa kojemu je renesansa kao vremenska, povijesna pojava i njeno značenje za kulturni razvoj isključivo afirmacija individualizma, trijumf svjetske radosti i životne sreće ("simfonija u C-duru"), duhovno osvajanje zemaljskog, životno i duhovno stajalište, najposlije i vrh svega, "nedjeljno ruho" (Schiffler 1993: 213). I dalje, ako razmišljamo o slojevima petrarkističkog pjesništva, talijanskih balada, a zatim i o hrvatskim renesansnim pjesnicima i hrvatskom modernom pjesništvu balada:

Odnos renesanse prema srednjovjekovnim oblicima mišljenja kao i prema modernoj kulturi pojmljiv je tek djelomice. Renesansa u cjelini ostaje neodredljiva, ostaje kao problem. Odnosi se to na renesansni antropocentrizam, na predodžbu čovjeka i svijeta, na sadržaj vjere. Pitanje ostaje otvoreno i poslije dijaloga neriješeno. Sliku renesanse moguće je vidjeti u kolebanjima i obratima, prijelazima i isprepletanjima kultura, u paradoksalnoj njezinoj složenosti, heterogenosti i pluralizmu njenih pojavnosti. (Schiffler 1993: 215)

Kako se folkloristika bavi i estetskim pitanjima, odbacivanjem ili barem problematiziranjem "inkluzije estetetike" iz vremena modernizma i avangarde (Posavac 2006: 70 i dalje), željeli bismo pokazati kako odabir i sučeljavanje estetskih mjerila iz usmene i pisane književnosti može riješiti neka od ključnih pitanja iz područja književnog stila i versifikacije, a to je, među ostalima, i pitanje formulaičnog građenja priče i zapleta balada te formulaičnog književnog stila općenito.

U ovome članku pokušat ćemo ukratko ocrtati lirske opise motiva ženske ljepote U tradicijskim pjesmama španjolske i hrvatske usmene tradicije s osvrtom na petrarkističke pjesme s motivom carpe diem. ${ }^{1}$ Teorijsku podlogu za komparativnu analizu čini teorija formulaičnosti usmenog i pisanog pjesništva Paula Zumthora (1983), te teorija o jeziku

\footnotetext{
${ }^{1}$ Ovaj rad predstavlja prerađeni tekst referata "The poetic topos of feminine beauty in modern poetic tradition of European Balladry and the presence of the formula of feminine beauty in examples of carpe diem Petrarchist poems", pročitanog na 42. konferenciji Međunarodne komisije za baladno pjesništvo, održanoj u Akyaki (Turska) od 7. do 13. listopada 2012., u organizaciji Sveučilišta Hacettepe. Dio je moje knjige u pripremi o petrarkizmu i usmenoj tradiciji. Usp. o tematološkom i o estetičkom problem "carpe diem" González de Escandón (1938). Za književnoteorijski okvir imenovanja “motivom” estetičkog problema "teme carpe diem" usp. Naupert (2003).
} 
i identitetu pjesme Karlheinza Stierlea (1999: 203-268). Riječ je o korpusima nejednaka opsega. Najopsežniji za interpretaciju bio je korpus hispanskih romanci i španjolskog petrarkističkog pjesništva šesnaestog stoljeća, ${ }^{2}$ pa ne isključujemo da je ta lektira utjecala i na čitanje hrvatskog usmenog i pisanog pjesništva. Kad je o španjolskom usmenom pjesništvu riječ, za istaknuti je da smo se, pored vrijednih rukopisa koji se čuvaju u Arhivu Ramón Menéndez Pidal u Madridu, oslanjali i na brojne zbirke hispanskog romancera iz različitih španjolskih regija. ${ }^{3}$ Hrvatski korpus "otvorio" nam se poglavito interpretacijom edicije zbirki tzv. "ženskih pjesama" iz niza Hrvatske narodne pjesme Matice hrvatske (1909-1942), ${ }^{4}$ kao i zbirki pripovjednog i baladnog usmenog pjesništva koje je u dvadesetom stoljeću objavio folklorist i književni prevoditelj Olinko Delorko $(1969,1976)$.

Osim toga, vjerujemo da je odabrani motiv povezan i s modusom transmisije usmenog pjesništva improvizacijom, odnosno memorizacijom, temom kojom su se opsežno bavili i još uvijek se bave folkloristi (od Menéndeza Pidala do Batesa Lorda), ${ }^{5}$ a koji možemo dovesti u vezu s različitim oblicima utjecaja orijentalnog pjesništva na hrvatsku i na španjolsku usmenu tradiciju. Ta bi tema svakako zasluživala podrobniju razradu, što prevazilazi intencije ovoga članka.

Treba istaknuti da izbor drevnog ovidijevskog motiva na primjerima poglavito sefardskog ogranka hispanskog romancera, te jednog fragmenta epske pjesme s Elafitskog otoka Šipana nije provizoran izbor. Odabir je motiviran estetskom kvalitetom otočke epike Kate Murat zabilježene u zbirci njezina sina, svećenika i Matičinog zapisivača Andre Murata u pjesmi "Ženidba kralja slovinskoga” (Murat 1996: 535).

Naravno, mogli bismo tu i stati pred neobičnošću tog lirskog fragmenta opisa ženske ljepote usred duge epske pjesme. Ipak, činilo nam se važnim istaknuti nekoliko činjenica, koje smo spoznavali postupnim uvidom u široki obim građe hrvatskog i hispanskog usmenog pjesništva. Tu prije svega mislimo na "neobičnost" usmenopjesničkog diskursa te pjesme Kate Murat, i toga fragmenta, i to $u$ kontekstu komparativnog proučavanja usmenog pjesništva na Mediteranu. Neobičnost je najuočljivija ne samo u prijenosu usmenopjesničke teme i motiva carpe diem, iznimno popularne $u$ istočnosefardskom ogranku hispanske romance La bella en misa, nego i u uvidu u jednakovrijednost načina transmisije usmenog pjesništva na koju nas je potaknula ljepota toga fragmenta. To ne znači da je uvid u supostojanje memorizacije i improvizacije bio i prije neizravno prezentan (usp. Delić 2001). Ipak, sravnjivanje epskog fragmenta i baladnih epsko-lirskih stihova španjolske romance dovelo nas je do zaključka o nedvojbenom utjecaju hispanskog romancera, a poglavito njegovog sefardskog ogranka, na korpus hrvatskog usmenog pjesništva, što se može objasniti u svjetlu prisustva Židova, poglavito Sefarda, na tlu Dubrovačke Republike

${ }^{2}$ Usp. Gutierre de Cetina (1990), Boscán (1999), de la Vega (1999), de Acuña (1982), de Herrera (1997), de Aldana (1997), de la Torre (1993).

${ }^{3}$ Catalán (2001), Catalán i Campa (1991); Petersen i dr. (1982), Valenciano i dr. (1998).

${ }^{4}$ Usp. Delić (1997: 79-94).

${ }^{5}$ Usp. primjerice Weber (1951), Miletich, (1981: 189-196; 1975: 51-69). 
(Stulli 1990; Posavac 1998). Riječ je o utjecaju kako na prostoru preuzimanja međunarodnih tema i motiva tako i na prostoru usmenopjesničkog diskursa, što je i opet razumljivo s obzirom na važnost ženske kulture najrazličitijih društvenih staleža u svijetu Dubrovačke Republike (usp. Miović 2013; Delić 2015; Faur 1990). ${ }^{6}$ Utjecaji turske epike na orijentalni karakter naših usmenih pjesama mogli bi se proširiti i uvidom u važnost turcizama i orijentalizama u komparativnom kontekstu usporedbe s hispanskim romancerom (Delić 2014).

\section{MOTIV ŽENSKE LJEPOTE U TRADICIJSKOM I U PISANOM PJESNIŠTVU}

Ženska ljepota, shvaćena doslovno, kao i simbolično, kao prirodna ljepota koja prožima našu ekološku nišu (isto), zaslužuje pozornost zbog svoje moći da objasni neobjašnjivo u ljudskoj prirodi, a koja se, zahvaljujući ponajprije kulturi i umjetnosti, odupire strogo znanstvenom pristupu prirodi shvaćenoj kao stroj. Stari mitovi o Erosu i Psihi, i o Veneri našli su svoj izražaj i u poeziji, usmenoj i u umjetničkoj, možda još neposrednije nego u proznim tekstovima (usp. Milićević 2004).

Motiv opisa ženske ljepote nije nepoznat $u$ tradicijskom pjesništvu, iako je često bio ublažavan humornim interpretacijama. Tema ili motiv ženske ljepote $u$ središtu je brojnih "starih" španjolskih, kao i starih hrvatskih tradicijskih balada, a nalazimo ga i kod većeg broja novijih tradicijskih ili pučkih pjesama u hrvatskoj, u španjolskoj pa i u europskoj usmenoj poeziji. Zanimljivo kako neke od tih pjesama, prilagođene suvremenim estetičkim idealima, ističu ideal umjetne (našminkane) ljepote. Tek odnedavna znamo da taj estetički ideal ima svoje korijene u starim priručnicima u kojima žene iz viših slojeva daju savjete puku kako ukrasiti svoj vanjski izgled ili duhovne kvalitete (Martínez Crespo 1996). U drugim tradicijskim, kao i u umjetničkim pjesmama, nailazimo na formulaični opis krhkosti ljepote i krhkosti prirode. Prisustvo motiva umjetne ljepote možemo objasniti i plodonosnim utjecajima i prepletanjima usmene i pisane književnosti. Opisi odjeće lijepe gospe ili dame predstavljeni su u svoj svojoj orijentalnoj dekorativnoj raskoši. Ljepota dijelova ženskog lica predstavljena je mineralnim metaforama i poredbama ljepote lica s dragim kamenjem, koraljima ili biserima, primjerice. Dvočlana struktura tih usporedbi u tradicijskom pjesništvu podsjeća na slične strukture u petrarkističkim pjesmama koje, naravno, poznaju i mnogo složenije slike, stoga i mnogo zahtjevniju estetiku, kao i mnogo složenije antropološke i psihoanalitičke strukture (usp. Bogdan 2002).

Kao potkrjepu dosadašnje argumentacije podastiremo jedan primjer iz hrvatskog i španjolskog tradicijskog pjesništva,? prije manje elaboriranih primjera iz pera petrarkističkih

\footnotetext{
${ }^{6}$ Zanimljiv je, međutim, uvid Vesne Miović u njezinoj knjizi Židovke u Dubrovačkoj Republici, na temelju podrobne analize i interpretacije dokumenata iz dubrovačkih arhiva, kako su židovske žene živjele ipak teže nego žene njihova društvena staleža u multikulturalnoj zajednici, iako je sredina bila načelno gostoljubivija od onih u drugim mediteranskim gradovima, primjerice španjolskim.

${ }^{7}$ Više o usporedbi tradicijskog hrvatskog i španjolskog pjesništva vidi u Delić $(2014,2012)$.
} 
pjesnika u hrvatskoj, španjolskoj i u talijanskoj tradiciji. Riječ je o jednom jedinom primjeru iz pjesme kazivačice Kate Murat iz Šipanske Luke na Šipanu u Dubrovačkom primorju. Zanimljivo je da kazivačica donosi opis umjetne (našminkane) ljepote, vjerojatno uslijed prepletanja usmenog i pisanog pjesništva - konstanti našeg mediteranskog pjesništva, o čemu su dosad pisali brojni folkloristi. Ipak, taj tako simptomatičan motiv ostao je dosad nezamijećen iako se u njemu najpregnantnije ističe plodonosni zajednički život usmene i pisane književnosti. $^{8}$

(...) Prođi me se, mila moja majko!

Velika se meni dogodila,

Mila moja, ne čudi se, majko, što ja svu noć u džardinu jesam; nit se čudi, mila moja majko, što mi je lišce tamno i blijedo ni što su mi oči zamućene ni što su mi kose rasprhane: kad sam sinoć u džardine došla, ja se penjem žute u naranče za utrgat' žut'jeh naranača, od naranče odlomi se grana, fati mi se grla i đerdana i svilen mi kavad zakinula i zlaćani đerdan prekinula, prospe mi se travi po zelenoj; svu noć n'jesam sanka boravila, neg' sam svu noć jadna preplakala, čekala sam mila moja majko, da osvane i ograne sunce, da pokupim po travi đerdane. O sna mi je lišce potamnjelo, ča od plača oči zamućene; naranča i kose rasprhala. S tez'jem mlada šeta u kamare i uzimlje vode od ružice i umiva b'jelo lišce svoje da je njome b'jelo i rumeno, stavi lišce svoje u bjelilo, u bjelilo i u rumenilo (...). ${ }^{9}$

${ }^{8}$ U kolovozu 1996. godina posjetili smo Luku na Šipanu, kao i župni dvor u kojem je djelovao sin kazivačice Andro Murat. Fascinirao nas je mir lijepog otoka, jednostavnost župnog dvora, kao i gostoprimstvo župnika koji nas je dočekao. On, doduše, nije puno znao o svojem glasovitijem prethodniku, ali nas je svojom neposrednošću približio "cifrastom" rukopisu Matičinog zapisivača.

${ }^{9}$ Andro Murat, Narodne pjesme iz Luke na Šipanu /kod Dubrovnika/ (ONŽO, MH 40), 1886. Rukopis u prijepisu čuva se u Institutu za etnologiju i folkloristiku, br. rkp. 163. 
I na sjeveru Hrvatske također postoji naznaka sličnog opisa ženske ljepote (usp. Žganec 2002), ali koji tek na Mediteranu dobiva opsežnu razradu, kao retorička figura hipotipoze, baš kao i u srpskoj narodnoj pjesmi iz Vukove pjesmarice:

Hvalila se Radulova Ana,

Hvalila se Radulova Ana,

Da je lipše u Novomu nema,

U Novomu ni okolo njega,

Ni u Splitu gradu bijelome.

Obrvice, morske pijavice,

tripavic, krilo lastavice,

dva solupa, dva ančela žuta,

usta su joj kutija šećera,

zubi su joj dva niza bisera,

a dvi dojke dva goluba bila,

dva obraza dva đula rumena,

dvi ručice, dvi ture pamuka,

a dvi noge, dvi burme od zlata,

a dva oka, dva vrana gavrana;

kad se smije, ko da biser sije,

kad govori, ko da golub guče,

kad igra, ko da paun šeće. ${ }^{10}$

A u Vukovoj pjesmarici (1846, cit. prema Zima 1988: 106):11

Pred dvorom se divno kolo igra,

Kolovođa sestra Stojanova,

A kakva je, da od boga nađe!

Oči su joj dva kamena draga,

Dva obraza dva đula rumena,

Obrvice, s mora pijavice,

Trepavice krila lastavice,

B'jeli zubi dva niza bisera;

A tanka je kako i šibljika,

Visoka je kako omorika;

Kada igra, kan'da paun šeće;

Kad govori, kan'da golub guče;

Kad se smije, kan'da sunce grije;

Pod grlom joj tri sitna đerdana,

Dva od zlate, treći od bisera,

Stoji zveka na vratu đerdana,

Stoji škripa skuta i sandala. (Vuk, 3, 35) 12

${ }^{10}$ Murat (1996: 535).

${ }^{11}$ Možda je riječ o Ziminoj udvornoj epistoli Vuku Stefanoviću Karadžiću jer se citirana pjesma ne nalazi u izdanju iz 1846. (usp. Vuk 1988 [1846]).

${ }^{12}$ Zima (1988: 106). 
Za usporedbu, u angloškotskim baladama taj je motiv iznimno rijedak, osim u baladi King Henry i tzv. pučkim broadside baladama. U talijanskim baladama, čini se, ti su se opisi transformirali u zaplet i priču. Jedino smo još u španjolskim baladama, a posebno u sefardskom ogranku, našli dugu hipotipozu descriptio mulieris. Analogna folklorna manifestacija koja ima usporednice u hrvatskom i u hispanskom folkloru, a u središtu koje je također žena jest moreška. Premda u njoj žena ima pasivnu ulogu, glamurozni kostimi i pomna koreografija, kao i borba dvaju tabora za naklonost dame, daju dignitet ženskom glavnom liku, pa je cijeli ples također svojevrsni "orijentalni opis ženske ljepote".

Još jedan primjer pjevačice Kate Murat iz pjesme "Vjerenica kralja budimskoga" u kojem se pripovijeda o udvornom odijevanju gospe, kao najava petrarkističkih sadržaja:

Kad to čula Ungarkinja Mare, ona se je na noge skočila, uzme hladne vode od ružice i umiva b'jelo lišce svoje. Stavi svoje lišce u bjelilo, u bjelilo i u rumenilo.

Pa se mlada stala resit' l'jepo: tri kavada na se oblačila, tri kavada jedan vrh drugoga; jedan kavad svile od šitkove, a drugi je svile od modrice, a treći je svile od bijele. Na vrat meće l'jepa tri đerdana, jedan đerdan od suhoga zlata, a drugi je šitkova koralja, a treći je b'jela od bisera.

Koji joj je suhoga od zlata, ti joj pada do svilena pasa; a koji je šitkova koralja, ti joj pada b'jelih do njedara; koji joj je b'jela od bisera, ti djevojci stoji oko vrata.

A kad se je l'jepo naresila, uzela je štitka svilenoga, kada buse goricom zelenom, što će mlada štitit' se od sunca. ${ }^{13}$

Kao svojevrsnu opoziciju seoskim hipotipozama, donosimo jedan "skulpturalni" primjer opisa ženske ljepote u iskazu lirskog subjekta, iz opusa Šiška Menčetića (Jukić 1998), kao svojevrsni odraz formula iz zbirke pjesama koje je zapisao Andro Murat:

${ }^{13}$ Murat (1996: 434). 
Zatoj se ja molju sve kako tužici, ne čini me da bolju u željnoj tužici; ne čin' me da sužu u željah čemerno, želeći da združu tvê ličce biserno želeći da grlim tvê grlo pribijelo. za koje ja hrlim dušu dati tijelo.

Pjesme Džore Držića “Draža je od zlata”, u kojoj adresat kao da je kći, "Od jele u gori”, "Moje čisto zlato", te pjesma "Ljubav jur vidim”, koju kao da je pisao Šiško Menčetić, također su na ravni urbanih formula iz usmenog pjesništva kakve nalazimo i na sjeveru Hrvatske:

Črne su ti jene oči, kak je terninica,

a slatka su jena usta, kak je jagodica. ${ }^{14}$

A u Džore Držića u pjesmi "Draža je od zlata", koja vjerujemo da opisuje "staru židovsku ljubav" Mojsijeva roda, ${ }^{15} \mathrm{~s}$ adresatom kćeri umjesto gospe, hipotipoza zauzima gotovo čitav prostor pjesme:

Ima rusi kosi jakno zlate žice, hladak iz uznosi na rajsko nje lice.

Oči joj jak zvizde gore u svitlosti

u nje su sve gizde i rajske milosti,

Oh, čarna dva vlasa vrh oči uzvita

lipa t' su, tanko t' su povita.

Rumen cvit ružice tere džilj pribili

jur cafti na lice gizdavoj toj vili.

Eto je prilike anđela smiljena

u koj su sve dike i sva moć ljuvena (...)

Lice, pogled i kosa tematiziraju se posebno u pjesmi Džore Držića "Ljubav jur vidim” (Jukić 1998) usporedbama s kozmološkim i prirodnim svijetom, koje u metaforički odnos uvlače i adresata pjesme, te više nije riječ samo o hipotipozi:

Jutroska cvitak urešen

cafteći lipo t' sjaše,

nu kad bi s suncu prinesen,

padnuv s zemlji usaše.

Ovakoj ja vas ublidih, srce t' mi žečjno strnu anđeosko ličce gdi t' vidih

da k meni, vilo, svrnu...

Evo t' me držiš za sužna

kosom me sveza rusom,

\footnotetext{
${ }^{14}$ Žganec (2002: 31).

${ }^{15}$ Čuva je i katedrala u mjestu Monreale na Siciliji.

${ }^{16}$ Bogišić (1975: 10).
} 
sobom me vodiš pritužna

jak lovac zvor pod uzom.

Cjelokupna povijest pjesništva, pa i književnosti, mogla bi se opisati s obzirom na transpoziciju retoričkih figura lirskog subjekta prema adresatu svojih pjesama. ${ }^{17}$ Pjesme Džore Držića, posebno pjesma "Moje čisto zlato", kao da imaju za lirski subjekt svećenika, iako većina ima platonski lirski subjekt koji bi trebao biti i norma, s obzirom na to da pjesme funkcioniraju kao srednjovjekovni “dijalog duše i tijela”, prebačen često i na "romantizirano" divljenje Gospi. Opće mjesto neosvojivosti Gospe zna se konkretizirati u temu neosvojivosti osmijeha, i kroz druge metafore njezine neosvojivosti (pogled, jelen).

Šišmundo Menčetić odabrao je lice i "grlo", kao simbol ljepote djeve u pjesmi "Gizdava diklice":

Zatoj se ja molju sve kako ružici, ne čin'n me da sužu u željnoj tužici; ne čin' me da sužu u željah čemerno, želeći da združu tvê ličce biserno, želeći da grlim tvê grlo pribijelo, za koje ja hrlim dušu dat i tijelo.

"Pjesme na narodnu" kao da su most između hrvatskog i španjolskog pjesništva, o čemu svjedoči i formulaični opis lica u petrarkističkom pjesništvu i hipotipoze tijela u hrvatskom tradicijskom pjesništvu. Maja Bošković-Stulli i Olinko Delorko u svojim antologijama uvijek su posebno isticali romansko-mediteranski supstrat hrvatskog usmenoga pjesništva, čitanje kojega priziva hrvatske petrarkističke kanconijere, pa i temu opisa ženske ljepote i motiv carpe diem, povezan s temama higijene i kozmetike.

\section{FORMULA LJEPOTE U HISPANSKOM I U SEFARDSKOM USMENOM TRADICIJSKOM PJESNIŠTVU}

Slijedi primjer jedne "stare" španjolske romance (romances españoles viejos) "La ermita de San Simón" (Wolf i Hofmann 1899), koja je objavljena kao tradicijska balada u šesnaestom stoljeću, a koja također pripada korpusu tzv. međunarodnih balada (usp. Delić 2011). ${ }^{18}$ Ta je romanca poznata u brojnim varijantama u modernoj hispanskoj tradiciji, a ovdje je donosimo u prijevodu na hrvatski:

\footnotetext{
${ }^{17}$ Usp. Taschenove foto monografije Davida Robinsona o Greti Garbo (2007) ili Eymanovu o Ingrid Bergman (2007). Vjerujemo da su autori knjiga o ženskoj ljepoti u belle epoque razdoblju svoju inspiraciju, osim u povijesnim ženama, crpili i u lirskom pjesništvu (usp. Turudich 2011, 2013). Filmska umjetnost interiorizirala je $u$ isto doba i duhovnu dimenziju spiritualnog pjesništva, pa je koncept filmske dive povezan s njime.

${ }^{18}$ Za baladu međunarodnog tipa poznatu u hispanskoj tradiciji pod naslovom "La bella en misa" usp. Catalán (1998).
} 
En Sevilla está una hermita cual dicen de San Simón, adonde todas las damas iban a hacer oración.

Allá va la mi señora, sobre todas la mejor, saya lleva sobre saya, mantilla de un tornasol, en la su boca muy linda lleva un poco de dulzor, en la su cara muy blanca lleva un poco de color, y en los ojuelos garzos lleva un poco de alcohol, a la entrada de la hermita relumbrando como el sol, El abad que dice la misa no la puede decir, non, monacillos que le ayudan, no aciertan responder, por decir: amén, amén, decían: amor, amor

U Sevilli ima jedna kapelica, kapelica Sveti Šimun, kamo sve gospe idu, moliti se Svevišnjemu.

Tamo kroči moja gospa, najljepša je među svima, suknju nosi preko suknje, plašt od suncokreta, njezina su lijepa usta,slađa od šećera, na svome blijedom licu nosi malo rumenila, crne oči sjajne i blistave, na ulazu u kapelicu blješti jače od sunca.

Opat koji govori misu, mora prekinuti molitvu, Ministranti koji mu pomažu, ne uspijevaju uzvratiti, Tamo gdje bi trebali reći amen, zbore ljuveni plam. ${ }^{19}$

Navela sam nekoliko primjera formulaičnog opisa koji je možda i rezultat utjecaja muslimanske baladne tradicije ili tradicije pjesama sevdalinki na hrvatsko tradicijsko pjesništvo (usp. Maglajić 1970), ili je možda riječ također o prepletanju usmene i pisane književne petrarkističke tradicije. U slučaju španjolskog romancera, opće je mjesto u studijima romancera - primjerice u glasovitoj studiji Diega Catalána- Menéndeza Pidala - da je opis ženske ljepote $u$ romanci "La bella en misa" rezultat sefardske adaptacije izvorno grčke balade koja je kasnije tradirana ostatku hispanske tradicije zahvaljujući prisustvu Katalonaca u Grčkoj u doba renesanse (usp. Catalán 1998). Ne ulazeći u pojedinosti o profilu kazivača i njegovom obiteljskom statusu - s obzirom na to da raspolažemo samo s imenom kazivačice i s nazivom lokaliteta gdje je pjesma zapisana, koja je jedna od brojnih pjesama koje se bile objavljene u ediciji "ženskih pjesama” Matice hrvatske (usp. Andrić $1909,1914,1929$ ) - iskustvo proučavanja pisane književnosti pomaže nam kao i inače u prepoznavanju estetskih kvaliteta usmenoknjiževnog teksta. Možda je katalonska balada "La bella en misa" motiv opisa ženske ljepote preuzela iz sefardske tradicije na Balkanu, ${ }^{20}$ iako hrvatska tradicija ne posjeduje međunarodni korelativ toj europskoj baladi. Nije riječ o epskoj preradi međunarodne balade jer se stil naše pjesme dijametralno razlikuje od

19 Sve primjere pjesama sa španjolskog jezika, osim ako nije drugačije naznačeno, prevela je i/ili prepjevala autorica rada.

${ }^{20}$ Usp. Armistead (1978: 192-197). Romanca je u Arhivu Ramón Menéndez Pidal prisutna u verzijama zabilježenima ponajviše u Bosni i Hercegovini (Sarajevu). Postoji trag da su pojedinačne verzije bile omiljene i u Grčkoj (Solunu, Rodosu), te u Turskoj (Istanbulu, Smirni) i Izraelu. 
grčke, tj. katalonske balade. A i riječ je o različitim zapletima! Naša namjera nije razmotriti individualne poetike pojedinih španjolskih pjesnika, kao što su, primjerice, Garcilaso de la Vega ili Gutierre de Cetina, kao ni hrvatskih petrarkističkih pjesnika, poput Šiška Menčetića ili Džore Držića (usp. Jukić, ur. 1998); niti komentirati svijet tradicijskog pjevača, iako ćemo uzeti u obzir intersubjektivni karakter usmene književnosti i usporediti ga s individualističkim petrarkističkim kanconijerom ili s pjesmama "ljubavi razlike". Usporedbi simbola u narodnoj i u pisanoj književnosti u ovom članku posvetit ćemo pozornost ne samo na tematskoj razini nego i na (meta)diskurzivnoj razini.

Kad je riječ o diskurzivnoj razini usmenih pjesama, podastrijet ćemo još nekoliko primjedbi o staroj raspravi između tzv. tradicionalista i "lordparryjevske škole" prije no što donesemo još nekoliko primjera motiva ženske ljepote u tradicijskoj i u pisanoj književnosti.

Prema Lordu i Parryju pjevači nisu memorizirali tekst stih po stih, nego su tekstove pamtili i prenosili oslanjajući se na svoju intuiciju, trudeći se kako bi što fluentnije ovladali pojedinim pjesničkim jezikom. Ta metoda učenja tekstova, odnosno njihova memorizacija, može bitno promijeniti naslijeđene tekstove, i uvesti neke bitne varijacije, i to veće nego što ih nalazimo u španjolskoj usmenoj tradiciji. S druge strane, škola tradicionalista, kojoj je na čelu bio Ramón Menéndez Pidal, i koju je nastavio Diego Catalán-Menéndez Pidal i znanstvenici okupljeni oko Arhiva Ramón Menéndez Pidal, nastavili su i dalje zagovarati važnost proučavanja "neprekidnog obnavljanja naslijeđenih tekstova, kroz mnogobrojne neovisne inicijative otvorene stalnim estetskim i etičkim obnavljanjima koje su specifične za svako pojedino vremensko razdoblje" povijesti španjolske književnosti (usp. Catalán 1997, 1998). Školu okupljenu oko lika i djela Alberta B. Lorda više zanima proces obnavljanja, ili mehanizam tradicijskog stvaranja, iako se ti znanstvenici ne posvećuju tumačenju dijakronijskog aspekta te tradicije. Naprotiv, koncept formule bio je mnogo ovisniji o memorizaciji u "tradicionalističkoj školi", čak i kod proučavanja zamjene duljih paradigmatskih nizova drugima. Formulu Catalán shvaća kao metaforu koja se može zamijeniti nekom drugom formulom s time da se značenje ne mora mijenjati, ili se, naprotiv, stubokom mijenja.

Prema "tradicionalistima", tzv. profesionalne kazivače uglavnom nije zanimala estetska struktura ispripovijedanih (epskih) pjesama, bez obzira na to što su folkloristi ukazivali na važnost pisane književnosti, na tradiranje tema i motiva, primjerice, na utjecaj talijansko-francuskih viteških romana (usp. Bošković-Stulli 1978: 7-53; Armistead 1990: 323-339).

Zahvaljujući studijama o tradicijskom pjesništvu, kao i studijama topike i motiva, počelo se govoriti i o formulaičnoj naravi učenog pjesništva. U studijama o romanceru taj se metodološki pristup već dugo primjenjuje, iako je oduvijek isticana specifičnost tradicijskog pjesništva u odnosu na učeno. Tako je isticano kako su isti procesi - inovacije i memorizacije - vodili prenošenju kvalitativno različitih tradicijskih i učenih tekstova, s obzirom na narav kreativnog pjesničkog stvaranja u tradiciji i u individualnim uobličenjima naučenih zapleta kod usmenih "pripovjedača priča” (usp. Bénichou 1968). Međutim, Ramón Menéndez Pidal ustvrdio je kako "prerađivanjâ tradicijskih tekstova nisu slučajni procesi, kao što je slučaj s preradama u pisanom učenom pjesništvu", koje prenosi i 
nasljeđe kulture dokolice u kojoj je književni fenomen vjerojatno i nastao. Usmeni tekstovi slijede "tradicionalna pravila" i "kolektivne tendencije"; u protivnom, došlo bi do zaborava tradicijskog teksta. Naposljetku, francuski medievist i znalac tradicijske književnosti, Paul Zumthor (1983), istaknuo je formulaični karakter književnosti općenito, iako smatra da postoje različiti tipovi formulaičnosti.

Ukoliko se sada osvrnemo na "staru" španjolsku baladu koju smo citirali, moći ćemo istaknuti nekoliko uvida. Opis ženske ljepote započinje nabrajanjem djevine odjeće, nakon čega slijedi tročlana enumeracija dijelova ženskoga lica: usta, lica, očiju. Oči su našminkane i ne pokazuju ženinu prirodnu ljepotu. Balada završava sažetkom svih učinaka koji na lirskoga subjekta ostavlja gospina ljepota.

Riječ je o dvočlanoj konstrukciji koja zauzima oba polustiha; slike su jednostavne i reducirane na realistično predstavljanje boja, od kojih su dvije jako učestale u tradicijskom pjesništvu, bijela i crvena, a treća vrlo rijetka - "garzo" - "crna boja". Pripovjedač pripada figuri muža, a ne dragoga. Te formule u staroj španjolskoj romanci imaju funkciju isticanja ljepote dame, ljepote koja prožima sveto mjesto, crkvu. Ljepota nije protivna svjetovnoj ljubavi; naprotiv, ona kontaminira i crkvu i svećenike. Ukoliko usporedimo tu baladu s petrarkističkim pjesništvom, prepoznajemo kako takav stil nije u suprotnosti kultu ženske ljepote iz petrarkističkih pjesama, iako je humoristički ton tipičniji za kasnije (bembističke) petrarkističke pjesme (usp. Čale 1971). Prepoznajemo razlike u predstavljanju ljepote kao umjetne (našminkane) ljepote, na mjestu gdje bi slična petrarkistička topika donijela niz mineralnih ili biljnih metafora, i gdje bi lirski subjekt bio muž, tj. vitez jer ni u hrvatskoj tradiciji, kao ni u sefardskoj, ne postoji razlika između individualnog i kolektivnog.

U različitoj i bogatoj židovsko-španjolskoj tradiciji nailazimo na estetski vrlo uspjele primjere na ladinu u Bosni i Hercegovini, Grčkoj, Turskoj i u Maroku, koji se također proučavaju u kontekstu hispanskog romancera. U kastiljskoj i katalonskoj tradiciji nailazi se također na vrlo uspjele inačice, iako ova balada pripada tzv. rijetkoj tradiciji romanci (romances raros) prema Armisteadu i Silvermanu (1971). Samo šest verzija - pet kastiljskih i jedan portugalski fragment - čuva se u Arhivu Ramón Menéndez Pidal, u usporedbi s osamnaest židovsko-španjolskih verzija na ladinu iz istoga Arhiva.

Struktura "stare" španjolske romance načelno je zadržana: opis započinje nabrajanjem gospine odjeće i nastavlja se opisom ljepote dijelova damina lica; drugi polustih specificira o kojem se tipu ljepote radi. Varijacija je strukturalna: primjerice, u jednoj verziji iz Soluna u Grčkoj nailazimo na amplifikaciju: umjesto dvaju odjevnih predmeta ističu se četiri komada odjeće.

(...) Tres damas van a la misa por hacer la oración, entre media la mi esposa, telas de mi corazón.

Sayo lleva sobre sayo y un jiboy d'altanación.

Camisa de Holanda lleva, sirma y perla al cabezón.

Su cabeza una toronja, su cabellos briles son, cuando los quita a peinares en ellos despunta el sol. 
La su frente reluciente que bola la raya del sol,

La su cejica narcada arcos de tirar ya son;

los sus ojos lindos pretos, višnas de Stambol ya son. ${ }^{21}$

Tri dame idu na misu ne bi li se pomolile,

među njima i moja supruga, prirasla mome srcu.

Suknju nosi preko suknje i prsluk raskošni (?).

Košulju iz Holandije nosi, srebro i zlato na ovratniku.

Njezina je glava grejpfrut, njezine su kose sjajne (?),

kad ih raščešljava, o njih se ogleda Sunce,

Njezine obrve kao lukovi poput luka iz kojih se strelica odapinje;

Njezine crne oči, istambulske su višnje.

Umjesto triju dijelova ženskog tijela, možemo naći čak i osmerodijelne opise. Osim toga, varijacija nije samo strukturalna nego i tematska. Nailazimo na topiku koja pripada biljnome svijetu (primjerice grejpfrut ili "jabuke iz Skopja” u inačici iz Istanbula koja se koristi za poredbu s gospinim licem). Naići ćemo i na novu mineralnu topiku kao što je zlato, biseri ili carigradsko zrcalo, kao drugi član usporedbe sa zubima ili s očima, ili nailazimo na ratnu topiku: gospine obrve uspoređuju se s lukom (primjerice u Yoninoj verzija iz Soluna). U verziji iz Soluna koju je prikupio etnomuzikolog Manuel Manrique de Lara 1911. godine od Lucíje Saltiel de Yeudá, žene u kasnim četrdesetim godinama, tijekom velike akcije prikupljanja sefardskog romancera u različitim zajednicama na Balkanskom poluotoku i u Turskoj, nailazimo na metaforu naliv-pera za nos. Neobičnost te metafore danas se može prepoznati čak i u realijama trgovine Mont Blanc, primjerice u lijepom belle epoque Mont blanc naliv-peru, model Ingrid Bergman. ${ }^{22}$

U varijanti iz oblasti Huesca u Aragónu, u Španjolskoj, naišli smo na ove stihove koje je zapisao poznati sakupljač hispanskog romancera Eduardo Torner, u mjestu Castillazuelo u regiji Barbastro 1917. godine:

Por los ríos más corrientes donde baja el agua clara

Yo vi bajar una niña blanca, rubia y colorada.

Lleva la luna en los pies el sol en su blanca cara,

Las estrellas por vestido, por ir mejor adornada,

Una matita de pelo que a sus plantas le llegaba,

Si se lo peina de día, sólo en verlo el Sol se para,

Si se lo peina de noche, todo el pueblo relumbraba,

Son sus narices dos fuentes que manan perlas tempranas,

Los dientes piñones de oro, su lengua barra de plata,

\footnotetext{
${ }^{21}$ Attias (1961), Pascual Recuero (1977).

${ }^{22}$ Nedavno smo naišli na ono što se može shvatiti amplifikacijom te metafore u novinarskom diskursu kad smo u jednom elektroničkom broju dnevnih novina El País, nadnevka 26. kolovoza 2012. godine, pročitali vijest o "portugalskom Schindleru", konzulu Aristidesu de Sousa Mendesu koji je, vjerujemo, spašavao živote svojim naliv-perom izdajući vize Židovima iz Bordeuxa da bi mogli pobjeći iz Francuske u lipnju 1940. godine, nakon nacističke okupacije. Sefardske kazivačice iz Zagreba potvrđuju prenošenje tradicijskog pjesništva i sefardskih balada, čak i u tako teškim trenucima kao što je zatočeništvo u fašističkim koncentracijskim logorima.
} 
Su cuellecito pequeño la gargantilla le tapa.

Lleva delantal dl cerpe? y la basquiña de grana. ${ }^{23}$

Tamo gdje rječica teče, gdje se spušta bistra voda

Vidjeh jednu djevu kako se spušta blijedoputu, plavokosu i rumenu.

Nosi Mjesec na stopalima, sunce na bijelom licu,

Zvijezde na odjeći, ne bi li ljepše bila urešena,

Duga pletenica spušta joj se do stopala,

Ako je češlja danju, kad to Sunce ugleda, stane,

Ako je češlja noću, cijelo selo obasjava,

Njezin su nos dva izvora iz kojih teku sitni biseri,

Zubi su joj zlatni pinjoli, njezin je jezik srebrena poluga,

Njezin sitni vrat pokriva ovratnik.

Nosi pregaču i grimiznu suknju.

Ukoliko se sada osvrnemo na petrarkističko pjesništvo, mogli bismo reći kako su opisi ženske ljepote kakve, primjerice, nalazimo u motivu carpe diem, prešli granice Zlatnog vijeka španjolske književnosti. Suptilne studije zabilježile su motiv u različitih pjesnikâ, u različitim žanrovima i u književnim pokretima sve do pjesništva dvadesetog stoljeća. Pjesma, uglavnom sonet, u kojem lirski subjekt hvali svjetovnu ljepotu svoje gospe, bio je osobito popularan među petrarkističkim pjesnicima šesnaestog stoljeća. Pjesnici poput Garcilasa, Herrere, Fray Luisa, pjesnici iz salamantinskih krugova (Medrano, de la Torre), ili iz seviljskih krugova (Mesa, Medina) prikazuju ljepote svoje gospe, opisujući dijelove njezina tijela i uspoređujući ga s budućim ili sadašnjim poružnjenjem koje je prouzročio, ili će prouzročiti, proces starenja. Ovisno o tome je li ljepota gospe aktualna ili ireverzibilno pripada prošlosti, retorička ekspozicija te njezin enkomijastički, persuazivni ili kritički karakter, bit će naglašeniji.

Kad su se španjolski pjesnici suočili s ovom topikom, mogli su računati na veliku i bogatu tradiciju u kojoj su i sami aktivno sudjelovali. Bili su čak i primorani da stave naglasak na vlastito sudjelovanje u tradiciji njegovanja tog carpe diem motiva. Učinili su to tako što su svoje sastavke označili "prijevodima” (primjer Fraya Luisa de Herrere). Taj je pjesnički imperativ imao važne posljedice za formulaični značaj tog pjesništva. Neke zajedničke slike prilagođavale su se metričkim i sintaktičkim potrebama tradicije. Primjerice, za opis lica korištena je dvočlana slika ruža/ljiljan, ruža/snijeg ili mlijeko/ruža. Međutim, svaka slika bila je specijalizirana za određeni kontekst: primjerice, slika ruža/snijeg ili snijeg/skrlet privlačila je druge "vatrene" metafore. S druge strane, slika ruža/ljiljan privlačila je slike biljnog tipa i stoga je bila jako pogodna za oblikovanje motiva carpe diem.

Španjolski pjesnici morali su istaknuti svoje poznavanje klasičnih modela tog motiva iako su se, ukoliko bi odabrali sonet kao pjesnički oblik, oslanjali na pjesničke modele talijanskih petrarkista. Donosimo nekoliko primjera pozitivnih i negativnih opisa ljepote u vremenskim zavisnim rečenicama u romanskim tradicijama (usp. González de Escandón 1938; Torner 1947).

${ }^{23}$ Transkripcija rukopisa iz mape "La bella en misa” (Arhiv Ramón Menéndez Pidal, Madrid, Španjolska). 


\section{Tasso}

Mentre che l'aureo crin v'ondeggia intorno a l'ampia fronte con leggiadro errore; mentre che di vermiglio e bel colore vi fa la primavera il volto adorno;

Mentre que v'apre il ciel piú chiaro il giorno, cogliete ô giovinette il vago fiore de vostri piú dolci anni; e con amore state sovente in lieto e bel soggiorno.

Verra poi l' verno, che di bianca neve suol i poggi vestir, coprir la rosa, e le piaggie tornar aride e meste.

Cogliete ah stolte il fior: ah siate preste, che fugaci son l'hore, e 'l tempo lieve, e veloce a la fin corre ogni cosa.

Dok zlatni pram lelujavo pada na široko čelo što bjelinom sjaji; dok proljeće vašega lica, stidom i ljepotom blista.

Dok vam sjajnom zorom započinje dan, djeve, ah, berite taj ljupki cvijet vaših najslađih godina; i s ljubavlju uživajte u ugodnim i lijepim danima.

Imate vremena za zimu da bijelim snijegom prekrije planinu, i sakrije ružu, da žalo ostane pusto i jalovo.

Berite ponosno cvijet; avaj, požurite jer sati brzo minu, i laki sati; i svemu hitro stigne kraj.

\section{Garcilaso}

En tanto que de rosa y azucena Se muestra la color de vuestro gesto, Y que vuestro mirar ardiente, honesto, Enciende el corazón y lo refrena;

$\mathrm{Y}$ en tanto que el cabello, que en la vena Del oro se escogió, con vuelo presto, Por el hermoso cuello blanco, enhiesto, El viento mueve, esparce y desordena.

Coged de vuestra hermosa primavera El dulce fruto, antes que el tiempo airado Cubra de nieve la hermosa cumbre.

Marchitará la rosa el vientoo helado, Todo lo mudará la edad ligera, Por no hacer mudanza en su costumbre.

Dok se ljiljan i ruža mirisava bojom na licu vašemu ogleda, dok čedna vatra vašega pogleda Svjetlošću čistom oluju svladava; dok vase kose, pomnjivo sabrane i privezane u vrpcu od zlata, vjetar vam mrsi oko bijelog vrata, Vijoreć njima žurno na sve strane; proljeća vašeg berite što prije plodove slatke, dokle bijesno vrijeme Vrhunac lijepi snijegom ne pokrije.

Jer hladni vjetar ruži smrt zadaje i sve će brzo promijeniti vrijeme, koje ne mijenja svoje običaje.

Prepjev: Nikola Miličević (1973: 147) 


\section{Cristóbal de Mesa (1)}

En tanto que el color de nieve y grana Adorna vuestro alegre rostro bello, Y que el gallardo error del rubio vello Esmalta vuestra frente soberana,

Y que al fino oro en lustre y gracia gana Vuestro precioso lúcido cabello, Y al márfil deja atrás el gentil cuello, Poniendo en duda, o no, si sois humana.

De esa flor, de ese lirio, de esa rosa, $\mathrm{Y}$ amena primavera, que florida, Dulce os promete grato pasatiempo,

Coged el fruto con la breve vida. Que la edad pasa y muda toda cosa, Y todo al fin tras sí lo lleva el tiempo.

Dok snijeg i skrlet

Krasi vaše lijepo i vedro lice,

I dok ponos vaših plavih prama,

Krasi vaše divno čelo.

I dok ljepša je i divnija od sjajnoga zlata, Vaša krasna sjajna kosa,

I dok alabaster nadvisuje bijeli vrat, Pa ne znam jeste li boginja il' djeva.

Od tog cvijeta, tog ljiljana, od te ruže, I ugodnog proljeća, koje cvjetno Nježno obećava vam krasne sati.

Berite plodove kratkog života. Jer vrijeme teče i sve prolazno jest, I sve naposljetku sa sobom nosi vrijeme.

\section{Francisco de la Torre}

(...) Agora que el oriente de tu belleza reverbera, agora que el rayo transparente de la rosada Aurora abre tus ojos, y tu frente dora; antes que la dorada cumbre de relucientes llamas de oro húmida y argentada quede, inútil tesoro consagrado al errante y fio corro, goza Filis del aura que la concha de Venus hiere; dado que apenas se restaura el contento pasado, como el día de ayer y el no gozado.

Vendrá la temerosa noche de nieblas, y de vientos llena; marchitará la rosa purpúrea, y la azucena nevada mustia tornará de amena.

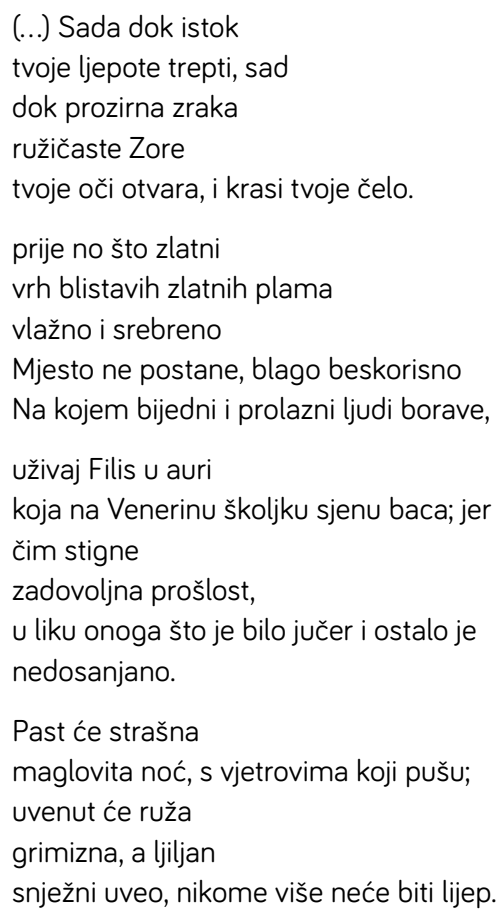


Usporedili smo i suočili opise ženske ljepote u različitih petrarkističkih pjesnika u romanskim tradicijama, uključujući i one pjesme u kojima prevladava negativan opis ženske ljepote (usp. González de Escandón 1938; Torner 1947), te ih sravnili s primjerima iz usmenog pjesništva. U ovome sam članku željela istaknuti formulaičnu narav opisa ženske ljepote u petrarkističkom, kao i u tradicijskom pjesništvu, koje je ženskoj ljepoti željelo podariti mitski status reprezentativnosti, ${ }^{24}$ stavljajući na trenutak između zagrada individualni značaj svakog od spomenutih pjesnika, kao i individualni značaj pojedinog kazivača ili kazivačice. Drugim riječima, mogli bismo taj motiv pratiti u cjelini njegova oblikovanja u povijesti okcidentalnih ideja i estetike. Od Gombrichove povijesti umjetnosti (1995) do neke obuhvatne povijesti estetskih ideja o ženskoj ljepoti na tragu Povijesti ljepote Umberta Eca (2004). Očito je i zašto je taj motiv privukao pozornost "svakodnevnih filozofa". Krhkost svijeta u kojem živimo, a koji svoj odjek nalazi u biljnim i mineralnim ili klimatskim metaforama kao i u spoznaji o povezanosti čovjeka, krajolika i prirode u tradicijskom i u petrarkističkom pjesništvu (usp. Gunnell 2008), omogućuje da nas uvijek iznova iznenade multikulturalna obilježja i estetske kvalitete usmenopjesničkih tekstova. Vjerujemo da je koncept formule i stalnih motiva u pisanom pjesništvu izraz divljenja proučavatelja književnosti estetskim uspjesima usmenog pjesnika.

Iz aspekta folklorističke teorije memorizacija i improvizacija kao oblici izvođenja usmenog pjesništva, poglavito ženskih kazivača usmenih balada na širokom prostoru Mediterana, otkrivaju nam se i opet kao inačice jedne te iste izvedbene umjetnosti kazivanja priča u stihu u kojoj se stihovi mogu nizati u beskonačnost ukoliko zadrže stup "ljepote zapleta" ili barem jednostavnog frazema stiha i dvostiha. I za estetski uspjele balade vrijedi "etika bajke" o kojoj je pisao G. K. Chesterton (1970: 182) kao "etici uvjetovane sreće”: vizija sreće u bajci uvijek ovisi o nekom uvjetu, a taj je uvjet najčešće nerazumljiv (npr. "Možeš sretno živjeti s kraljevnom AKO joj ne pokažeš luk!"). Stoga bismo, na tragu ove analize, mogli zaključiti da kulturološki pristup usmenom pjesništvu, kao i književnosti uopće, može rezultirati vrijednim uvidima u povijest ideja o ženskoj ljepoti, kozmetici i higijeni.

Formula ljepote ne može se preuzeti ni od koga, može se otkriti sama za sebe i onda njegovati.

\section{NAVEDENA LITERATURA I IZVORI}

Acuña, Hernando de. 1982. Varias poesías. Luis F. Díaz Larios, ur. Madrid: Cátedra, Letras Hispánicas. Aldana, Francisco de. 1997. Poesías castellanas completas. (2. izd.). José Lara Garrido, ur. Madrid: Cátedra, Letras Hispánicas.

Andrić, Nikola. 1909. Hrvatske narodne pjesme, 5. Ženske pjesme: romance i balade. Zagreb: Matica hrvatska.

Andrić, Nikola. 1914. Hrvatska narodna pjesma, 6. Ženske pjesme: pričalice i lakrdije. Zagreb: Matica hrvatska.

${ }^{24}$ Nalik slici ljepote prikazane na slici "Venerino zrcalo" (1877) prerafaelitskog slikara Sir Edwarda Coleyja Burnea-Jonesa ili nekim drugim njegovim uobličenjima. 
Andrić, Nikola. 1929. Hrvatske narodne pjesme, 7. Ženske pjesme: ljubavne pjesme. Zagreb: Matica hrvatska.

Armistead, Samuel G. i Joseph H. Silverman. 1971. The Judeo-Spanish Chapbooks of Yacob Abraham Yoná. Berkeley: University of California Press.

Armistead, Samuel G. 1978. El Romancero judeo-español en el Archivo Menéndez Pidal (Catálogo índice de romances y canciones) por Samuel G. Armistead con la colaboración de Selma Margarettan, Paloma Montero, y Ana Valenciano. Madrid: Cátedra Seminario Menéndez Pidal.

Armistead, Samuel G. 1990. "Afterword". U The Bugarštica. A Bilingual Anthology of the Earliest Extant South Slavic Folk Narrative Song. Urbana, Chicago: University of Illinois Press, 323-339.

Attias, Moshe. 1961. Romancero sefardí. Romanzas y cantes populares en judeo-español. Jeruzalem: Instituto Ben-Zewi, Universidad Hebrea.

Bénichou, Paul. 1968. Creación poética en el romancero tradicional. Madrid: Gredos.

Bogdan, Tomo. 2002. Ljubavi razlike. Tekstualni subjekt u hrvatskoj ljubavnoj lirici 15. i 16. stoljeća. Zagreb: Disput.

Bogišić, Rafo. 1975. Hrvatski petrarkisti (Antologija). Zagreb: Mladost.

Boscán, Juan. 1999. Obra completa. Carlos Clavería, ur. Madrid: Cátedra, Letras Hispánicas.

Bošković-Stulli, Maja. 1978. "Usmena književnost". U Povijest hrvatske književnosti, 1. Usmena i pučka književnost. Zagreb: Liber, Mladost, 7-353.

Catalán. Diego. 1997. Arte poética del romancero oral, 1. Madrid: Siglo Veinti uno editores.

Catalán, Diego. 1998. Arte poética del romancero oral, 2a. Memoria, invención, artificio. Madrid. Siglo veintiuno editores, Fundación Ramón Menéndez Pidal.

Catalán, Diego. 2001. El Archivo del Romancero. Patrimonio de la Humanidad. Historia documentada de un siglo de historia, 1-2. Madrid: Fundación Menéndez Pidal.

Catalán, Diego i Mariano de la Campa, ur. 1991. Romancero General de León. Antología 1899-1989, 1-2. Madrid: Fundación Ramón Menéndez Pidal, Diputación Provincial de León.

Čale, Frano. 1971. Petrarca i petrarkizam. Zagreb: Školska knjiga.

Cetina, Gutierre de. 1990. Sonetos y madrigales completos. (2. izd.). Begoña López Bueno, ur. Madrid: Cátedra, Letras Hispánicas.

Chesterton, Gilbert K. 1970. G. K. Chesterton. A Selection from his Non-Fictional Prose (selected by W. H. Auden). London: Faber and Faber.

Delić, Simona. 1997. "Matičine zbirke ženskih pjesama. Sto godina nakon edicije Hrvatske narodne pjesme (1896-1942)". Narodna umjetnost 34/2: 79-94.

Delić, Simona. 2001. Između klevete i kletve. Tema obitelji u hrvatskoj usmenoj baladi. Zagreb: Hrvatska sveučilišna naklada.

Delić, Simona. 2011. Silva Hispanica. Komparativna studija o žanru balade u modernoj hrvatskoj španjolskoj usmenoj tradiciji. Zagreb: Institut za etnologiju i folkloristiku.

Delić, Simona. 2012. Barca Bela. El Género de la Balada en el Mediterráneo. Los Aspectos TeóricoLiterarios y Literario-Antropológicos de la Tradición Oral Croata e Hispánica del Siglo XX. Saarbrücken: Editorial Acdémica Española.

Delić, Simona. 2014. "Metafora ljepote grada Dubrovnika i Granade kao slika utjecaja pjesništva orijentalnog drugog u hrvatskoj bugarštici Prijatelj Dubrovčanom i u španjolskoj romanci Abenámar". Anali Zavoda za povijesne znanosti Hrvatske akademije znanosti i umjetnosti 52/1: 219-233. [https://doi.org/10.21857/y7v64twqky]

Delorko, Olinko. 1969. Ljuba Ivanova. Hrvatske starinske pjesme sakupljene u naše dane po Dalmaciji. Split: Matica hrvatska.

Delorko, Olinko. 1976. Narodne pjesme otoka Hvara. Prema zapisima osmorice sabirača Matice hrvatske u devetnaestom stoljeću. Split: Čakavski sabor.

Eco, Umberto. 2004. Povijest ljepote. Zagreb: HENA COM.

Eyman, Scott. 2007. Ingrid Bergman (Movie Icons). Paul Duncan, ur. Hong Kong i dr.: Taschen. 
Faur, José. 1990. "Four Classes of Conversos. A Typological Study", Revue des etudes juives 149: 1-3. [https://doi.org/10.2143/REJ.149.1.2012742]

Vega, Garcilaso de la. 1999. Poesía castellana completa. (21. izd.). Consuelo Burell, ur. Madrid: Cátedra, Letras Hispánicas.

Gombrich, E. H. 1995. The Story of Art. (16. izd.). London: Phaidon.

González de Escandón, Blanca. 1938. “Los temas del ‘Carpe diem’ y la brevedad de la rosa en la poesía española". Barcelona: Universidad de Barcelona.

Gunnell, Terry, ur. 2008. Legends and Landscape. Articles Based on Plenary Papers Presented at the 5th Celtic-Nordic-Baltic Folklore Symposium. Reykjavik: University of Iceland Press.

Herrera, Fernando de. 1997. Poesía castellana original completa. (21. izd.). Cristóbal Cuevas, ur. Madrid: Cátedra, Letras Hispánicas.

Maglajić, Munib. 1970. 101 sevdalinka. Mostar: Prva književna komuna.

Martínez Crespo, Alicia. 1996. Manual de mugeres en el qual se contienen muchas y diversas eçeutas muy buenas. Salamanca: Ediciones Universidad Salamanca.

Menčetić, Šiško i Džore Držić. 1998. Ranjinin zbornik. Sanja Jukić, ur. Vinkovci: Riječ.

Miletich, John S. 1975. "The South Slavic Bugarštica and the Spanish Romance. A New Approach to Typology". International Journal of Slavic Linguistics and Poetics 21/4: 51-69.

Miletich, John S. 1981. "Repetition and Aesthetic Function in the Poema de Mio Cid and South-Slavic Oral and Literary Epic". Bulletin of Hispanic Studies 58/1: 189-196. [https://doi.org/10.3828/ bhs.58.3.189]

Miličević, Nikola. 1973. Zlatna knjiga svjetske ljubavne poezije. (3. dopunjeno izd.). Zagreb: Nakladni zavod Matice hrvatske.

Milićević, Nikola. 2004. Antologija španjolskog pjesništva. Zagreb: Školska knjiga.

Miović, Vesna. 2013. Židovke u Dubrovačkoj Republici. Zagreb, Dubrovnik: Hrvatska akademija znanosti i umjetnosti.

Murat, Andro. 1886. Narodne pjesme iz Luke na Šipanu /kod Dubrovnika/ (ONŽO, MH 40). Zagreb: Institut za etnologiju i folkloristiku, rkp. 163.

Naupert, Cristina. 2003. Tematología y comparatismo literario. M. Beller, C. Bremond, S. Chatman, L. Doležel, E. Frenzel, G. Kaiser, J. Schulze, W. Sollors, W. Theile, R. Trousson. Madrid: Acro/Libros, S. L.

Petersen, Suzanne H. i dr., ur. 1982. Voces nuevas del romancero castellano-leonés. Madrid: Editorial Gredos.

Posavac, Zlatko. 2006. "O istraživanju povijesti estetike. Problem estetike moderne zapadnjačke kulture s implikacijama što ih nosi hrvatska estetika". Prilozi za istraživanje hrvatske filozofske baštine 63-64: 69-149.

Pascual Recuero, Pascual. 1977. Diccionario básico ladino-español. Barcelona: Ameller ediciones.

Robinson, Michel. 2010. Turner. His Life and Works in 500 images, London: Lorenz Books.

Robinson, David. 2007. Garbo (Movie, Icons). Paul Duncan, ur. Hong Kong i dr:: Taschen.

Schiffler, Ljerka. 1993. "Renesansa kao problem". Prilozi za istraživanje hrvatske filozofske baštine 3738: 209-221.

Stierle, Karlheinz. 1999. "Lenguaje e identidad del poema. El ejemplo de Hörderlin". Teorías sobre la Lírica. G. Agamben, D. Combe, J. Ferraté, J. G. Merquior, J. M. Pozuelo Yvancos, J. M. Schaeffer, K. Stierle, R. Wellek. Madrid: Arco/Libros, S. L., 203-268.

Stulli, Bernard. 1990. Židovi u Dubrovniku (Jews in Dubrovnik). Zagreb: Jevrejska općina Zagreb, Nakladni zavod Matice hrvatske, Kulturno društvo "Dr Miroslav Šalom Freiberger".

Torner, Eduardo M. 1947. Poesía popular española. Indice de analogías entre la lírica española antigua y la moderna. Syracuse, New York: Department of Romance Languages, Centro de Estudios Hispánicos.

Torre, Francisco de la. 1993. Poesía completa. (2. izd.). María Luisa Cerrón Puga, ur. Madrid: Cátedra, Letras Hispánicas. 
Turudich, Daniela. 2001. 1940s Hair Styles. Chicago: Streamline Press.

Turudich, Daniela. 2013. Art Deco Hair. Hairstyles from 1920s\&1930s. Chicago: Streamline Press.

Valenciano, Ana, José Luis Forneir, Concho Enríquez de Salamanca i Suzanne Petersen, ur. 1998. Romancero xeral de Galicia. Os romances tradicionais de Galicia. Catálogo exemplificado dos seus temas. Madrid-Santiago de Compostela: Publicaciones do centro de investigaciones linguísticas e literarias, Fundación Ramón Menéndez Pidal.

Weber, Ruth House. 1951. Formulistic Diction in the Spanish Ballad. Berkeley, Los Angeles: University of California Press.

Wolf, Fernando José i Conrado Hofmann. 1899. Antología de poetas líricos castellanos, 8. Romances viejos castellanos (Primavera y flor de romances). M. Menéndez Pelayo, ur. Madrid: Librería de Hernando y Compañía.

Zima, Luka. 1988. Figure u našem narodnom pjesništvu [Pretisak izdanja JAZU iz 1880.]. Zagreb: Globus. Zumthor, Paul. 1983. Introduction a la poesie orale. Paris: Editions du Seuil.

Žganec, Vinko. 2002. Hrvatske pučke pjesme iz Međimurja. Zagreb: Zavod za istraživanje folklora.

\section{DESCRIPTIONS OF FEMININE BEAUTY IN THE POETIC TRADITION OF EUROPEAN BALLADS AND PETRARCHIST POEMS}

This article presents an account of lyrical descriptions of the motif of feminine beauty in Spanish and Croatian oral tradition, paying special attention to Petrarchist poems with the carpe diem motif. Feminine beauty, taken literally and symbolically as natural beauty that permeates our ecological niche, is treated here as having ecological power to explain the unexplainable (unsayable) in Nature and in Humankind. Thanks to its cultural and artistic manifestations, it stands in opposition to a purely scientific approach to Nature, taken as a Machine. The paper presents a comparison of symbols of beauty in oral and written Croatian and Spanish literature, paying special attention to the thematic level as well as the discursive and metadiscursive level. The thematic and discursive aspect of poetry is based on the theory of the "formulaic nature" of the literary phenomenon, proposed by Paul Zumthor. Some poems in both the oral and the written tradition adopt contemporary esthetic ideals, laying emphasis on the ideal of artificial (made-up) beauty. The presence of the motif of artificial beauty may be explained by the fact that oral and written literature underwent fruitful encounters and are inextricably intertwined. Examples from Croatian and Hispanic oral tradition are provided; specifically from the coastal region around Dubrovnik (Luka on the island of Šipan) and from the Castilian, Sephardic tradition of the ballad "La bella en misa". The argumentation is accompanied by a general and more specific interpretation of Petrarchist poetry compared for the first time in the context of the two oral poetry traditions. Many examples from the Hispanic tradition as reflected in the ballad "La bella en misa" find its counterpart in a single example of poetic discourse of the famous epic song and ballad singer, Ms. Kate Murat from the Dubrovnik region. Similar dual structures in both the traditional and artistic natural description of feminine beauty are recognized, according to Paul Zumthor's terminology. We highlight the formulaic nature of the description of feminine beauty in Petrarchist and in traditional poetry, which gave it a mythical status of representativeness, disregarding for the moment the individuality of each individual poet as well as the individual impact of the epic and ballad singer. It is obvious why the motif of feminine beauty has attracted the attention of "everyday life philosophers", i.e. of traditional singers, who, in these cases, come from urban, bourgeois surroundings. The fragility of the world we live in, which is echoed in floral and mineral or climatic metaphors in traditional and in Petrarchist poetry, may have its origin in the interdependence of the Humankind and landscape and traditional poems, and warrants laying stress on the (multicultural) esthetic qualities of the analyzed poetic texts.

Keywords: Petrarchist poems, ballad poetry, formulaic descriptions of feminine beauty, Paul Zumthor, Kate Murat, story narrator 